\title{
Sustainable management of fisheries resources in Java Sea: Utilization status of longtail tuna (Thunnus tonggol) in Indramayu waters West Java case study
}

\author{
Gatut Bintoro*, Daduk Setyohadi, Tri Djoko L, Rofiiqoh Affif N, Almira Syawli, and Muammar Kadhafi \\ Fisheries and Marine Science Faculty, Universitas Brawijaya, Veteran Street 65145 Malang, Indonesia
}

\begin{abstract}
Longtail tuna (Thunnus tonggol) is a pelagic fish which is generally found in tropical waters. Research on fishery resource sustainability by applying bioeconomic and length weight assessments is necessary to be done in order to determine status of longtail tuna. This research was conducted in south part of Java Sea namely Indramayu waters West Java from January 2020 to April 2020 which aims to estimate utilization status of longtail tuna (T. tonggol) namely exploitation rate, Maximum Sustainable Yield (MSY), Total Allowable Catch (TAC), Maximum Economic Yield (MEY), and Open Access (OA), and to determine length and weight relationship. The research used quantitative descriptive method based on catch and effort data from 2010 to 2019 as well as length weight primary data as much as $987 \mathrm{fish}$. Result showed that catch and effort at MSY level was 8,453 tons/year and 2,974 trips/year respectively with value of TAC as much as 6,762 ton/year. While the estimated values of catch and effort at MEY level was 8,168 tons/year and 2,427 trips/year with optimum profit as much as 88.98 billion Indonesia dollar rupiah (IDR). Another analysis indicated that OA level was achieved when effort reached at 4,855 trips/year and whilst exploitation rate was $93 \%$. Meanwhile length weight relationship analysis showed that fish had a balance length weight growth which $\mathrm{b}$ value $=3.039$ with equation $\mathrm{W}=0.0147 \mathrm{~L}^{3.0393}$. In conclusion, the fish has an isometric length weight relationship and the utilization status of fish is in fully exploited condition hence additional fishing effort must be prohibited in order to maintain stock sustainability.
\end{abstract}

\section{Introduction}

Java Sea, including Indramayu waters, has high potency of marine fisheries resource. Indramayu Regency has three small islands, namely Biawak Island, Gosong Island and Candikian Island. Karangsong Fish Landing Base (FLB), in Indramayu, is one of the fish landing baes for pelagic fish catches and one of the busiest fisheries landings in Indramayu [1].

Longtail tuna (Thunnus tonggol) is a type of pelagic fish that is oceanodromous and its population is mainly in clear neritic waters. This fish is spread throughout the Indo-West Pacific region from northern Australia, Papua New Guinea and Indonesia, while from the northwest through Malaysia and Thailand, continues to spread to the northeast and south of Japan, northwest of Iran to the Red Sea. Longtail tuna (T. tonggol) is the second smallest of the eight species Thunnus, growing to a maximum size of $142 \mathrm{~cm}$ and a weight of $35.9 \mathrm{~kg}$. This type of longtail tuna (T. tonggol) is generally the target of fishing in purse seines, gill nets, and line fishing [2].

The bioeconomic approach used in this research is surplus production. While there is no information about economic benefits regarding with fisheries resource utilization, it hopes that through this approach, the estimation of biological values can be known and achieve sustainable welfare. Utilization of fishery resources must be based on socio-economic aspects as well as fish biology, sustainability and environmental conditions to support sustainable utilization activities. Management of fishery resources is how the activities of utilizing these resources produce high economic benefits for users, but their sustainability is maintained [3].

The analysis of the length and weight relationship is intended to measure the variation in expected weight for a certain length of fish individually or in groups of individuals as an indicator of obesity, health, gonad development, and so on. Another usefulness of lengthweight relationship analysis is that it can be used to estimate condition factors or often referred to as the index of plumpness, which is one of the important derivatives of growth to compare the relative health condition or condition of a particular fish population or individual regarding with resource sustainability [4].

\section{Methodology}

The material used in this research is longtail tuna ( $T$. tonggol) caught in Java Sea and landed at the Karangsong FLB, Indramayu, West Java. The observations made were regarding with the length and weight relationship and fish samples were taken as many as 987 fish. The bioeconomic aspect uses tuna resource

\footnotetext{
* Corresponding author: gbintoro@ub.ac.id
} 
data from 2010-2019 which were obtained from statistical data from the Karangsong FLB, Indramayu Regency, West Java. The study also used direct observation and descriptive measurements of length and weight of fish. The data used are longtail tuna production, fishing effort in trip units and catch per unit Effort (CPUE). The length and weight sizes were measured directly, the data obtained were processed using Microsoft Word and Microsoft Excel software.

\subsection{Data analysis of length weight relationship}

Relationship of length and weight is estimated based on the cubic model [5-7] in the exponential equation:

$$
\begin{aligned}
& \mathrm{W}=\mathrm{a} \operatorname{Lb}(1) \\
& \text { Where: } \\
& \mathrm{W}=\text { fish weight }(\mathrm{g}) ; \\
& \mathrm{L}=\text { length of fish }(\mathrm{TL}=\mathrm{mm} \text {, or } \mathrm{cm}) ; \\
& \mathrm{a}=\text { constant, and } \\
& \mathrm{b}=\text { allometric constant; }
\end{aligned}
$$

Estimation of constants $\mathrm{a}$ and $\mathrm{b}$ is done by transforming the cubic equation above into a linear equation:

$$
\operatorname{Ln}(\mathrm{W})=\operatorname{Ln}(a)+b \operatorname{Ln}(\mathrm{L})
$$

The estimation of the values $a$ and $b$ is based on the linear regression approach (value intercept and regression direction coefficient). The increase in fish body length is equal to the increase in weight so it is called an isometric growth model $(b=3)$, a deviation of the value of $b$ from 3 is called an allometric growth model. Value $b>3$, then the shape of the fish tends to be fat (an indication of the availability of natural food), while the value of $b<3$ indicates the opposite. The length weight relationship is part of fish biology data to illustrate fish stock sustainability $[8,9]$.

\subsection{Fishing effort standardization}

The formula for standardization calculation of fishing gear [10] is as follows:

$$
\begin{aligned}
& \mathrm{Pj}=\mathrm{Uj} / \mathrm{Us} \\
& \mathrm{Ejt}=\mathrm{Pj} . \mathrm{Tjt} . \mathrm{Vjt}
\end{aligned}
$$

Where:

$\mathrm{Pj}=$ Average fishing power of fishing gear $\mathrm{j}$, with constant value every year;

$\mathrm{Uj}=$ Average vessel productivity using fishing gear $\mathrm{j}$;

Us = Average productivity of fishing gear s;

Ejt $=$ Fishing effort of fishing gear $\mathrm{j}$ year $\mathrm{t}$;

$\mathrm{Tjt}=$ Average fishing days of vessel $\mathrm{j}$ year $\mathrm{t}$; and

$\mathrm{Vjt}=$ Amount of vessel $\mathrm{j}$ year $\mathrm{t}$.

\subsection{Maximum sustainable yield calculation}

\subsubsection{Schaefer (1954) model}

Optimum fishing effort rate (fMSY) and the maximum sustainable catch (YMSY) can be known by the following equation:

a. Relationship between catch (Y) and fishing effort (f)

$$
\begin{aligned}
& Y=a f+b f 2 \\
& Y / f=U=a+b f
\end{aligned}
$$

b. The maximum sustainable effort ( $\mathrm{f}_{\mathrm{MSY}}$ ) is obtained from equation (7) as follows:

$$
\begin{aligned}
& \text { Y/f }=a+2 b f \\
& 0=a+2 b f \\
& a=2 b f \\
& f_{\text {MsY }}=-a / 2 b
\end{aligned}
$$

c. The maximum sustainable catch ( $\left.\mathrm{Y}_{\mathrm{MSY}}\right)$ is obtained by substituting the optimum effort value ( $f_{M S Y}$ ) to equation (5),

$$
\begin{aligned}
& \text { YMSY }=a f_{\text {MSY }}+b f_{\text {MSY }^{2}} \\
& \text { YMSY }=-a^{2} / 4 b
\end{aligned}
$$

The calculation of the catch per fishing effort (UMSY) is obtained by the formula equation:

$$
\mathrm{U}_{\mathrm{MSY}}=\mathrm{Y}_{\mathrm{MS}} / \mathrm{f}_{\mathrm{MSY}}
$$

Estimation of the Total allowable catch value $\left(\mathrm{Y}_{\text {тас }}\right)$ based on Schaefer model using the following equation:

$$
\begin{aligned}
& \mathrm{Y}_{\mathrm{TAC}}=-\mathrm{a}^{2} / 4 \mathrm{~b} \times 80 \% \\
& \mathrm{Y}_{\mathrm{TAC}}=\mathrm{Y}_{\mathrm{MSY}} \times 80 \%
\end{aligned}
$$

The estimated value of the allowable fishing effort $\left(f_{\text {тхс }}\right)$ can be found using the abc math formula with the following equation:

$$
T A C=\frac{a \pm \sqrt{\left.\left(a^{2}-4 b \times c\right)\right)}}{2 b}
$$

Where:

$\mathrm{Y}=$ Yield or catch (tonnes)

$\mathrm{f}=$ Effort or number of attempts to catch (trip)

$\mathrm{a}=$ intercept

$\mathrm{b}=$ slope

$\mathrm{c}=$ Total allowable catch (ton)

$\mathrm{Y}_{\mathrm{MsY}}=$ Maximum sustainable catch (ton)

$\mathrm{f}_{\text {MSY }}=$ Sustainable effort (ton)

$\mathrm{U}_{\mathrm{Ms}}=$ Maximum CPUE (ton/trip)

$\mathrm{f}_{\mathrm{TAC}}=$ Allowable effort (trip)

$\mathrm{Y}_{\mathrm{TAC}}=$ Allowable catch (tonnes) 


\subsubsection{Fox (1970) model}

The assumption of Fox's (1970) exponential model is that the population is considered not to be extinct $[5,7$, 11]. The Fox method uses an exponential pattern based on equation:

$$
\begin{aligned}
& \frac{y(i)}{f(i)}=e^{(c+d * f(i))} \\
& Y(i)=f(i) * e^{(c+d * f(i))}
\end{aligned}
$$

Where:

$\mathrm{c}=$ intercept

$\mathrm{d}=$ slope

From this equation, a derivative equation is obtained to work out the utmost sustainable catch the maximum sustainable fishing effort as follows:

$$
\begin{aligned}
& f_{M S Y}=-\frac{1}{d} \\
& Y_{M S Y}=-\frac{1}{d * e^{(c-1)}}
\end{aligned}
$$

\subsection{Maximum economic yield (MEY) calculation}

Calculation of possible maximum economic yield can be gained is often obtained using the Gordon-Schaefer method of calculation, which uses the principle of total revenue (TR) minus total costs (TC):

$$
\begin{aligned}
& \pi=T R-T C \\
& \pi=\boldsymbol{p} . \boldsymbol{Y}-\boldsymbol{C} . \boldsymbol{f}
\end{aligned}
$$

Where:

$$
\begin{aligned}
& \pi=\text { profit } \\
& \mathrm{p}=\text { average fish price (IDR/kg) } \\
& \mathrm{y}=\text { volume of production }(\mathrm{kg}) \\
& \mathrm{c}=\text { monetary value per trip (IDR/trip) } \\
& \mathrm{f}=\text { catch effort (trip) }
\end{aligned}
$$

Analysis of maximum economic yield (MEY) can be calculated based on the equation of [12]:

$$
\begin{aligned}
f_{F A E} & =\left(\left(\frac{c}{p}\right)-a\right) \\
Y_{F A E} & =\frac{(c * p)}{f_{F A E}} \\
f_{M E Y} & =\frac{1}{2} f_{F A E}
\end{aligned}
$$

Where:

$\mathrm{f}_{\mathrm{FAE}}=$ Effort to catch at the equilibrium point

$\mathrm{Y}_{\mathrm{FAF}}=$ The catch at the purpose of balance

$\mathrm{f}_{\mathrm{NEY}}=$ Sustainable economic fishing effort

a $=$ intercept

$\mathrm{b}=$ slope

Then to determine the value of sustainable economic catch $\left(\mathrm{Y}_{\mathrm{ME}}\right)$ it can be calculated by substituting the value of $\mathrm{f}_{\mathrm{MEY}}$ into the equation as follows:

$$
Y_{M E Y}=a x f_{M E Y}+b x f_{M E Y}^{2}
$$

\subsection{Utilization Rate (UR)}

The calculation of the percentage value in biology that has been used will be known using the following formula:

$$
\mathrm{UR}=\left(\mathrm{f} / \mathrm{f}_{\mathrm{TAC}}\right) \times 100 \%
$$

The calculation of the percentage value economically that has been utilized can be found using the following formula:

$\mathrm{UR}=\mathrm{f} / \mathrm{f}_{\text {MEY }} \times 100 \%$

Where :

$\mathrm{f}_{\mathrm{t}} \quad=$ Last year's catch

$\mathrm{f}_{\mathrm{TAC}}=$ Total allowable catch

$\mathrm{f}_{\mathrm{MEY}}=$ Economically sustainable effort

$\mathrm{UR}=$ Utilization rate

\section{Results}

Based on fishery statistics data at Karangsong FLB, Indramayu from 2010 to 2019 , longtail tuna production has fluctuated. (Fig 1).

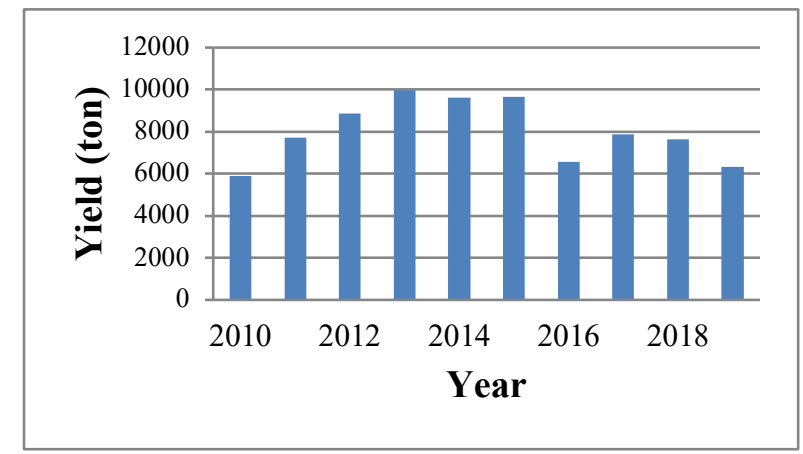

Fig. 1. Longtail tuna landed in Karangsong Indramayu (20102019).

Figure 1 above illustrates the catch of longtail tuna for a period of 10 years (2010-2019) at Karangsong FLB, Indramayu. The highest production occurred in 2013 with a volume of 9,968 tons and the lowest production occurred in 2010 with a volume of 5,877 tons.

The nature of fish growth can be divided into 2, namely isometric $(b=3)$ or length growth equivalent to weight growth, and allometric $(b \neq 3)$ or long growth does not equal weight growth. Growth Allometric can be divided into 2 , namely positive allometric ( $b>3$ or growth in weight faster than length growth) and negative allometric ( $b<3$ or growth in length faster than weight growth). Analysis of the length and weight relationship was used to determine the growth patterns of fish. Analyzing the relationship between length and weight of fish can use linear regression analysis with the model $\mathrm{W}$ $=\mathrm{aLb}$, where the values of $\mathrm{a}$ and $\mathrm{b}$ are obtained from linear regression analysis. The length-weight relationship of longtail tuna ( $T$. tonggol) is analized based on total data obtained by 987 fish. 
3.1 Length weight relationship

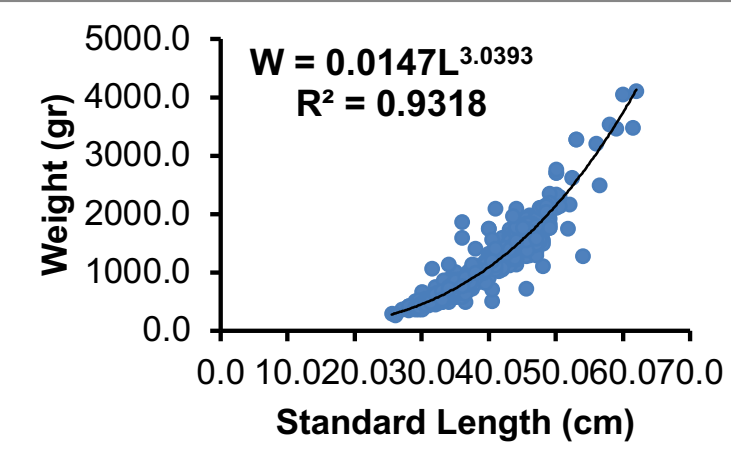

Fig. 2. Length weight relationship of longtail tuna in Karangsong, Indramayu.

Data analysis results for samples, heavy longtail tuna ( $T$. tonggol) shows that it is $\mathrm{W}=0.0147 \mathrm{~L} 3039$ (Fig. 2). It shows that seen from the growth of the weight gain of longtail tuna (Thunnus tonggol) is faster than the length of the fish ( $b>3)$. It is known that the b value is 3.0393, the $\mathrm{R}$ square is 0.9318 , the $\mathrm{t}$ value is 1.49 and the $\mathrm{t}$ table value is 1.96 . This shows that the value of $b>3$ and the value of $\mathrm{t}$ count $<\mathrm{t}$ table which means the weight and length of longtail tuna (T. tonggol) is isometric or balance length and weight growth.

\subsection{Fishing gear Standardization}

Standardization of fishing gear can be calculated after knowing the value of fishing power index (FPI). The FPI is the capability level of a fishing gear to catch a type of fish within a certain period of time. Calculating the FPI is necessary if a type of fish is caught using several fishing gears (Table 1).

Table 1. Productivity and FPI in Karangsong FLB, Indramayu (2010-2019).

\begin{tabular}{|c|c|c|c|}
\hline Fishing gears & $\begin{array}{c}\text { Produktivity } \\
\text { (kg/trip) }\end{array}$ & FPI & Rasio \\
\hline Millenium & $1,497.63$ & 1.00 & 1.00 \\
Gill net & 971.21 & 0.65 & 1.54 \\
Seine net & 973.75 & 0.65 & 1.54 \\
Hand line & 977.62 & 0.65 & 1.53 \\
Trammel net & 827.39 & 0.55 & 1.81 \\
\hline
\end{tabular}

Standardized fishing gear is used to know which fishing gear is the most dominant in catching tuna, this is used to determine unit of effort the standard before calculating the potential for sustainable fishing (MSY).

\subsection{Maximum sustainable yield (MSY) analysis}

Table 2. Effort, catch, CPUE, and Ln CPUE of longtail tuna in Indramayu West Java.

\begin{tabular}{|c|c|c|c|c|}
\hline Year & $\begin{array}{c}\text { Effort } \\
\text { (Trip) }\end{array}$ & $\begin{array}{c}\text { Catch } \\
\text { (Ton) }\end{array}$ & CPUE & $\begin{array}{c}\text { Ln } \\
\text { CPUE }\end{array}$ \\
\hline 2010 & 1623.0 & 5877.1 & 3.62 & 1.29 \\
\hline 2011 & 1906.0 & 7732.4 & 4.06 & 1.40 \\
\hline 2012 & 2356.0 & 8878.5 & 3.77 & 1.33 \\
\hline 2013 & 2883.0 & 9967.8 & 3.46 & 1.24 \\
\hline 2014 & 2562.0 & 9632.4 & 3.76 & 1.32 \\
\hline 2015 & 2802.0 & 9666.8 & 3.45 & 1.24 \\
\hline
\end{tabular}

\begin{tabular}{|l|l|l|l|l|}
\hline 2016 & 2371.0 & 6572.5 & 2.77 & 1.02 \\
\hline 2017 & 2659.0 & 7868.0 & 2.96 & 1.08 \\
\hline 2018 & 3282.0 & 7632.4 & 2.33 & 0.84 \\
\hline 2019 & 3665.0 & 6313.3 & 1.72 & 0.54 \\
\hline
\end{tabular}

\subsubsection{Schaefer (1954) Model}

The highest CpUE value was obtained in 2011 at 4.06 tonnes/trip, while the lowest value was in 2019 at 1.72 tonnes/trip. This CpUE catch has experienced changes that fluctuate from year to year (Table 2). Regression analysis of CpUE against effort indicated that value of intercept (a) and slope (b) was 5.6854 and -0.000955995 respectively (Fig. 3). Hence non linear equation of MSY based on Schaefer model was $\mathrm{Y}=5.6854 \mathrm{f}$ $0.000955995 \mathrm{f}^{2}$. With the result of sustainable catch and effort 8453 ton/year and 2974 trip/year respectively (Fig. 4).

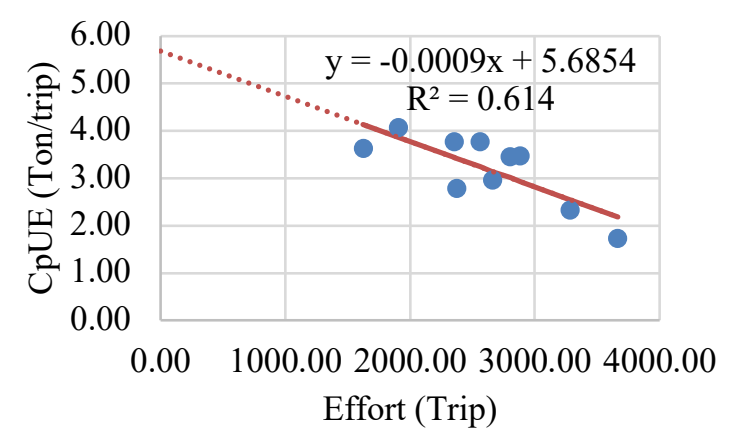

Fig. 3. Relationship between CpUE and effort of Schaefer model for Longtail tuna in Indramayu.

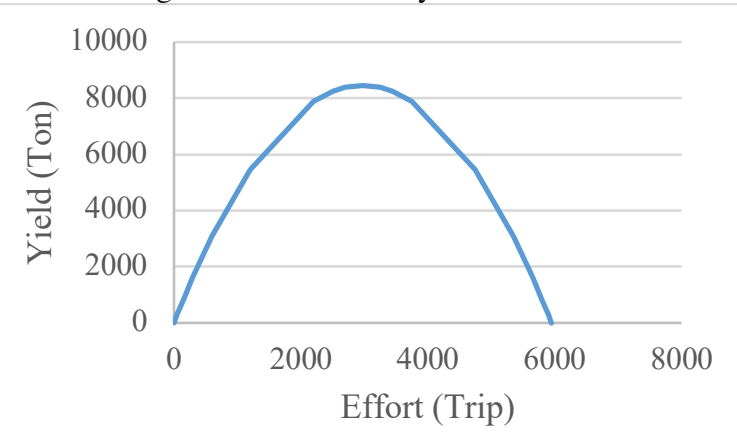

Fig. 4. Maximum sustainable yield (MSY) of Schaefer model for longtail tuna in Indramayu.

\subsubsection{Fox (1970) Model}

Calculation the maximum sustainable yield (MSY) using Fox model required effort and $\ln$ CpUE data to apply regression analysis (Table 2). It was found that intercept (c) and slope (d) values were 2.040591946 and -0.0003484 respectively (Fig. 5). The Fox model uses the Gompertz growth function to analyze a surplus production model which results in an exponential relationship between fishing effort and population size and an asymmetrical production curve. Hence MSY calculation based on Fox model was 12,650 ton/year and 7,959 trip/year respectively. 


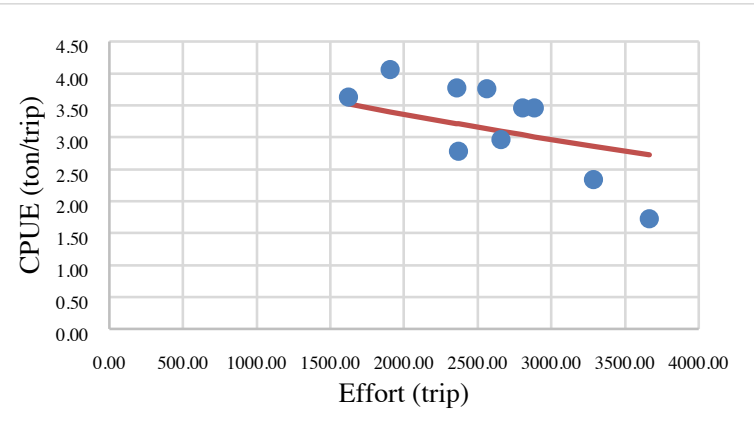

Fig. 5. Relationship between Ln CpUE and effort of Fox model for longtail tuna in Indramayu.

\subsection{Bioeconomic analysis of Gordon-Schaefer model}

Determining the MEY calculation that must be done is knowing the price of fish and the operational costs of fishing for tuna.

\subsubsection{Fish price}

Calculation of fish price can be done by identifying fish landed and production value in local fish landing place It was found that the fish price of longtail tuna at FLB Karangsong Indramayu in year 2019 was IDR 15.798 Million/ton.

\subsubsection{Operational costs}

The calculation of operational costs is obtained from the sum of fixed costs (fixed costs) andvariable costs. Fixed costs include depreciation costs of vessel, machinery, fishing gear and permit fees. The depreciation is obtained by applying calculation of fishing gear and equipment prices divided by their technical age. The variable costs include fishing accomodation, namely diesel, oil, consumption, ice block, and bait.

The proportion of catch of millenium fishing gear for long tail tuna based on production value is $31 \%$. The operational cost of millenium for fishing activity is 53.225 million IDR per trip. Hence, operational cost of the millenium to catch longtail tuna is of $16,499,750$ IDR/trip.

\subsubsection{MEY calculation}

After knowing operational costs and the price of tuna, then a sustainable economic catch potential will be calculated based on the formula equation of [12] as follow:

$$
\begin{aligned}
\mathrm{f}_{\text {MEx }} & =a p-c / 2 b p \\
& =(73,315,906 / 30,204) \\
& =2,427 \text { trip/year } \\
Y_{\text {MIx }} & =a^{2} / 4 b-c^{2} / 4 b^{2} \\
& =8,453-285=8,168 \text { ton/year }
\end{aligned}
$$

\subsubsection{Bioeconomic Analysis}

The catch shows that the production of longtail tuna is different at certain levels of effort. When fishing is still low, the increase in costs will follow the increase in business revenue so as to achieve economic balance (Table 3 and Fig. 6).

Table 3. Calculation of total revenues and total costs.

\begin{tabular}{|c|c|c|c|c|}
\hline Variable & $\begin{array}{c}\text { Existing } \\
\mathbf{( 2 0 1 9 )}\end{array}$ & MSY & $\begin{array}{c}\text { ME } \\
\text { Y }\end{array}$ & OA \\
\hline Catch (ton) & 6,313 & $\begin{array}{c}8,45 \\
3\end{array}$ & 8,168 & $\begin{array}{c}5,07 \\
0\end{array}$ \\
\hline Effort (trip) & 3,665 & $\begin{array}{c}2,97 \\
4\end{array}$ & 2,427 & $\begin{array}{c}4,85 \\
5\end{array}$ \\
\hline $\begin{array}{c}\text { Revenue } \\
\text { (Billion IDR) }\end{array}$ & 99.7 & $\begin{array}{c}133 . \\
5\end{array}$ & 129.1 & 80 \\
\hline $\begin{array}{c}\text { Cost } \\
\text { (Billion IDR) }\end{array}$ & 60.5 & 49.1 & 40.1 & 80 \\
\hline Profit & 39.3 & 84.5 & 89 & 0 \\
\hline (Billion IDR) & & & & \\
\hline
\end{tabular}

Total revenue earned is greater than the fishing costs incurred so that fishermen will get a large profit or profit until with the point of $\mathrm{F}_{\mathrm{MEV}}$.

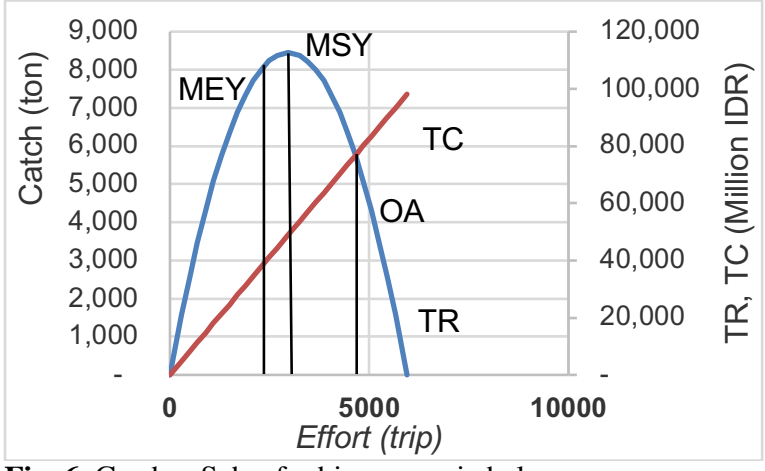

Fig. 6. Gordon-Schaefer bioeconomic balance.

\subsection{Estimation of utilization rate}

Estimation of the utilization rate of the Schaefer model using the equation UR $=\left(\mathrm{f}_{\mathrm{t}} / \mathrm{f}_{\mathrm{TAc}}\right) \times 100 \%$, where in the past 10 years, an average catch of 8,014 tonnes was obtained with a total allowable catch (TAC) value of 6,762 tonnes, so that the results of the Utilization Rate (UR) was $119 \%$. These results showed that the exploitation level of longtail tuna Indramayu waters in the period of 2010-2019 was in over exploited which means that the fisheries resources have been exploited over MSY level. So, it is recommended to reduce fishing effort because the stock has been disturbed.

Estimation of Fox model utilization rate (Table 4) using the equation UR $=\left(\mathrm{f}_{\mathrm{t}} / \mathrm{f}_{\mathrm{TAc}}\right) \times 100 \%$, where in the last 10 years an average catch was obtained of $8,014.12$ tons with a value total allowable catch (TAC) is 10,120 tonnes, so the results of Utilization rate (UR) of $79 \%$ show that the utilization rate of tuna landed in Indramayu waters in the period 2010-2019 is fully exploited, which means fish resources which have been 
exploited are close to the equivalent of $79 \%$ of MSY's value. Increasing the number of fishing efforts is not recommended although the number of catches can still increase but it can disrupt the preservation of longtail tuna resources.

Based on the economy, the number of sustainable fishing efforts $\left(\mathrm{f}_{\text {мЕх }}\right)$ is 2,427 trips/year, while according to social, sustainable catch efforts $\left(\mathrm{f}_{\mathrm{ox}}\right)$ of 4,855 trips/ year. Number of fishing gear MEY $\left(\mathrm{f}_{\mathrm{MEX}}=2,427\right.$ trips/ year) and social/open access ( $f_{o A}=4,855$ trips/ year). The number of fishing efforts will then be used as input data to estimate the level of exploitation of tuna resources in Indramayu waters (Table 5).

Table 4. Results of Analysis of Schaefer and Fox Model.

\begin{tabular}{|l|c|c|}
\hline \multirow{2}{*}{\multicolumn{1}{|c|}{ Variabel }} & \multicolumn{2}{c|}{ Analysis } \\
\cline { 2 - 3 } & Schaefer & Fox \\
\hline Intercept & 5.68539 & 1.46334 \\
\hline Slope & -0.00096 & -0.00013 \\
\hline $\mathrm{R} 2$ & 0.6147 & 0.01889 \\
\hline $\mathrm{F}_{\text {MsY }}$ (trip/year) & 2974 & 7959 \\
\hline $\mathrm{Y}_{\text {MsY }}$ (ton/year) & 8453 & 12650 \\
\hline $\mathrm{U}_{\text {MsY }}$ (ton/trip) & 2.84 & 1.59 \\
\hline $\mathrm{Y}_{\text {Tac }}$ (ton/year) & 6762 & 10120 \\
\hline UR & $93 \%$ & $62 \%$ \\
\hline Status & Fully Exploited & $\begin{array}{c}\text { Moderate } \\
\text { exploited }\end{array}$ \\
\hline Utilization & & \multicolumn{2}{|c|}{} \\
\hline
\end{tabular}

Table 5. Results of Analysis of the exploitation level and status.

\begin{tabular}{|c|c|c|}
\hline Variabel & MEY & OA \\
\hline F & 2.427 & 4.855 \\
\hline Y & 8.168 & 5.070 \\
\hline Y/F & 0.30 & 1.04 \\
\hline UR & $98 \%$ & $158 \%$ \\
\hline Status & Fully exploited & Depleted \\
\hline
\end{tabular}

The results of the economic analysis show that the level of exploitation of tuna resources is $98 \%$. This value indicates that the status of the tuna resources exploitation (fully exploited) is approaching and leads toover-exploitation. Results of social analysis or open access to get that level of exploitation of $158 \%$ indicates thestatus of utilizationdepletion(depleted) as well as fish resources have been exploited.

\section{DISCUSSION}

\subsection{Length Weight Relationship}

The results of the analysis of the relationship between length and weight obtained in this study indicate that the $\mathrm{b}$ value is 3.0393 , the $\mathrm{R}$ square is 0.9318 , the $\mathrm{t}$ count value is 1.49 and the $t$ table value is 1.96 . This shows that the value of $b>3$ and the value of $t$ count $<t$ table which means the weight and length of longtail tuna, ( $T$. tonggol) is isometric or length and weight are in balance growth, and the value of the coefficient of determination (R2) indicates that length growth affects fish weight growth. The multiple $r$ value is 0.9652 which indicates the degree of closeness between the length and weight variables which are closely related.

The length weight relationship of fish generally is influenced by gonad maturity. While isometric growth is proportional development between length and weight. There are differences in the nature of this growth because fish growth can be influenced by heredity, sex, age, disease, food availability and water conditions [13].

\subsection{MSY and MEY calculation}

Schafer and Fox models is applied to find out which one is the most appropriate to estimate the status of longtail tuna resource utilization. It can be seen from the $\mathrm{R}$ square value, if the $\mathrm{R}$ square value approaching the value of 1 , the model is getting better. $R$ square in the Schaefer model has a value of 0.614 while the Fox model has a value of 0.0188 , so it can be concluded that the appropriate and better model is the Schaefer model.

The coefficient of determination $\left(R^{2}\right)$ aims to determine how much influence the independent variable has on the dependent variable. The value of the coefficient of determination is in the range of $0 \leq R^{2} \leq 1$, which means that if the value of $\mathrm{R}^{2}$ approaches a value of 1 , it can be said to be independent variables on the dependent variable models used large means good and appropriate to clarify the effect of these variables [14].

Fishing effort will increase with increasing level of fishing effort. The total revenue is obtained by multiplying the price by the catch, while the total operational cost per trip is obtained by multiplying the fishing effort by the fishing cost per trip. Economic gain is the difference between the total revenue and the total cost for conducting a trip fishing.

Sustainable economic potential is the maximum value of the catch that can provide maximum benefits. MEY needs to be calculated so that the exploitation of fishery resources can run healthy and efficiently to get maximum benefits without disturbing the regeneration process or the recovery of these resources [7].

\subsection{Bioeconomics}

The total income earned is greater than the fishing costs incurred so that fishermen will get a large profit or profit up to the $\mathrm{F}_{\mathrm{Mer}}$. If the fishing business continues until $\mathrm{F}_{\mathrm{Ms}}$, then physically there will be a higher production but economically the profit will decrease. In this condition, it can be said that the fishing does not experience a loss because the total revenue is the same as the total expenditure, meaning that the tuna fishing effort has broken even.

In principle, the catch is the output of the fishing activity, while the effort required is the input of the fishing activity. In a production economy the comparison between output and input reflects the level of technical efficiency of each input use. Increased effort can also increase fishing costs, which means that 
increasing the use of fish resources beyond the maximum effort level in MEY can reduce the value of rent. The decline in rent value will not stop until it reaches a balance of open access [15].

The results of the economic analysis show that the level of exploitation of tuna resources is $95 \%$. This value indicates that the status of the tuna resources exploitation (fully exploited) is approaching and leads to over-exploitation. The results of the social analysis or open access show that the level of exploitation of $158 \%$ indicates the status of depleted utilization as well as exploited fish resources.

The catch of longtail tuna resources in Indramayu waters has been categorized as over exploited, fish resources have decreased because they are exploited more than MSY and MEY levels. This is in accordance with the Ministerial Decree NO. 45/MEN/2011 concerning the estimated potential of fish resources which states that fish resources have been categorized as over exploited in 2019. Fishing efforts must be reduced because the sustainability of fish resources has been disrupted.

\section{CONCLUSION}

Length weight relationship of longtail tuna (T. tonggol) is isometric or balance length and weight growth with equation $\mathrm{W}=0.0147 \mathrm{~L}^{\text {20.99 }}$. Value of maximum sustainable yield (MSY) takes place at 8,453 ton/year and 2,974 trip/year respectively with amount of TAC as big as 6,762 ton/year. While value of maximum economic yield (MEY) occurs at 8,168 ton/year and 2,427 trip/year respectively. In addition, utilization rate (UR) is $93 \%$ so that the status of the stock is fully exploited. Hence additional fishing effort of longtail tuna in Indramayu waters must be prohibited in order to maintain stock sustainability.

Acknowledgements: The authors sincerely thank the Fisheries and Marine Science Faculty, Universitas Brawijaya for providing the opportunity to carry out this piece of research and the Karangsong Fish Landing Base (FLB) staff members, Indramayu, West Java who have given permission to obtain field data. Last but not least, we would like to thank Prof Ali Suman (Research Institute for Marine Fisheries, Jakarta) for his nice review in this article.

\section{References}

1. G. Yulianto, S. Kadarwan, A. Lucky, Machfud. 2016. Demersal Fisheries Status in Indramayu adjacent coast West Java. Fisheries and Marine Faculty, IPB University, Bogor 10 (2016).

2. S.P. Griffiths, J Pepperell, M. Tonks, W. Sawynok, L. Olyott, S. Tickell, M. Zischke, K. Moyle. Biology,fisheries, and status of longtail tuna (Thunnus tonggol), with special reference to recreational fisheries in Australian waters. Final Report. Fish. Res. and Dev. Corp. and CSIRO Mar. and Atmosph. Res., 105 (2010).

3. A. Fauzi, and S. Anna. Fisheries and Marine Resource Modelling for Policy Analysis. Gramedia Pustaka Utama, Jakarta, 162 (2005).
4. A. Wujdi and Suwarso. Catch Fluctuation and Composition of neritic tuna caught by gill net in South China Sea. Tuna Fishery Research Institute. Benoa Bali, 8 (2014).

5. P. Sparre and S.C. Venema. Introduction to tropical fish stock assessment. Part I. Manual. FAO Fish. Tech. Paper. No.306 (1), Rev.2, 407 (1998).

6. D.G.S. Wiadnya. 1992. Analysis of Catch and Effort Data on Marine Capture Fisheries in East Java. Indonesia. Verslag Nummer 1376. Landbouw. Universiteit Wageningen. The Netherlands. Unpublished (1992).

7. G. Bintoro. Sustainable utilization of fringescale sardine (Sardinella fimbriata valenciennes, 1847) fishery in Madura Strait waters East Java. Disertation IPB University Bogor, 302 Unpublished (2005).

8. J.A. Gulland. Manual of the method for fish stock assessment part 1 fish population analysis. Fish. Science. FAO. 154 pp (1969)

9. D. Pauly. A Selection of sample method of the stock assessment of tropical fish stock. FAO. Journal of Fish. Science 727 pp (1980).

10. S.Y. Tai, and T. Heaps. Effort Dynamics and Alternative Management Policies For The Small Pelagic Fisheries of Northwest Peninsular Malaysia. Mar. Res. Ec. 11. USA. 85-103 (1996).

11. Fauziyah, A.I.S. Purwiyanto, F. Agustriyani, W.A.E. Putri, Ermatita, and A Putra. Determining the stock status of snapper (Lutjanus sp.) using surplus production model: a case study in Banyuasin coastal waters, South Sumatra, Indonesia. IOP Conf. Series: Earth and Env. Science 404. 012009. 12 (2020).

12. M. King. Fisheries Biology, Assessment and Management. Fishing News Books Ltd. Oxford, 341 (1995).

13. M.I. Effendie, 2002. Fisheries Biology. Yayasan Pustaka Nusantara. Bogor, 163 (2002).

14. Y. M. Harahap, F. Bu'ulolo, H. R. Sitepu. Several factors that influence the demand of fresh water consumption in local fresh water company (PDAM Indonesia) Tirtanadi Medan. J. Saintia Math. 1 (4), 325-336 (2013).

15. A. Fauzi. Fisheries Economics : Policy and Management Theory. Gramedia Pustaka Utama. Jakarta, 224 (2010). 